of the Museum's past and present achievement in this field of its work (this part being intended for circula. tion to local education authorities and other interested bodies), and (2) a full description of $(a)$ the requirements envisaged for a comprehensive service, and $(b)$ the minimum requirements for an initial trial period of five years. A full list of the material acquired by the various departments during the year is to be found in Appendixes I-III, and Appendix IV lists publications by members of the staff. The usual list of the publications of the National Museum of Wales appears in Appendix VII.

\section{Agricultural Museums?}

Tне Agricultural History Society (Washington, D.C.) was founded in 1919 "to stimulate interest in, to promote the study of, and to facilitate research and publication on the history of agriculture". In Vol. 19 (July 1945) of the Society's quarterly journal Agricultural History, Herbert A. Kellar has contributed a paper on "Living Agricultural Museums", in which he shows how much the museum may do to promote the aims of the Society. Notable progress has been made in the museum idea since 1920, particularly as regards the importance attached to accuracy, the introduction of motion into the exhibits and the recognition of the necessity for an appropriate setting for the objects. As an illustration of the latter, he describes a recreated village typical of rather more than a century ago that has been set up near Springfield, Illinois, where no modern effects are allowed to detract from the reality of the scene. His conception of a national agricultural museum is particularly ambitious, as he envisages an institution where not only the historical and social aspects of agriculture should be portrayed by means of exhibits, but which should also act as headquarters of important national farm organisations, and serve as a centre for educational activities, with special library and theatre attached. Branch museums specializing in matters of local interest, such as the Farmers Museum spon. sored by the New York Historical Association at Cooperstown, are suggested as extensions of the central unit. Here exhibits of both indoor and outdoor forms of agricultural operations might well be compared with those of earlier periods, illustrating, for example, the evolution of machinery, transportation, milling, tanning or other processes.

\section{Electricity Supply Legislation in Britain}

A PAPER read in London on February 7 by W. Fennell before the Institution of Electrical Engineers examines a number of the legal provisions regulating the relations and rights as between undertakers and consumers of electricity. Suggestions are made as to revision which is necessary to promote the further expansion of the industry and the maintenance of good relations with consumers. Among other matters, the author deals with the existing complicated provisions in the Electric Lighting (Clauses) Act of 1899, which intending consumers can follow in any application for a supply of electricity; with service connexions ; with charges for supply; with the authorization of inspection and inquiry; and with meters.

\section{Fate of German Ornithologists}

Mrs. Margaret Nice, the well-known American ornithologist, has heard from Dr. Stresemann that Dr. Konrad Lorenz, one of the pioneers in the study of behaviour, notably in birds, whose probable death was reported in Nature of November 10, 1945, p. 578, is alive. $\mathrm{He}$ is a prisoner in Russian hands, unwounded, and employed as a camp physician. The same letter also contains news of other German ornithologists : Dr. Steinfatt is in Denmark, but will shortly be returning to Germany; Dr. Meise is alive, but still in Russian hands.

\section{Advanced Lectures on Special Librarianship}

THE Association of Special Libraries and Information Bureaux hopes to organise a course of advanced lectures on special librarianship during the period May to July 1946, to be given at the London School of Hygiene and Tropical Medicine, Keppel Street, Gower Street, W.C.l. It is proposed to hold the lectures in pairs on a Friday evening and the following Saturday morning with a fortnight's interval between each pair. No examination will be held. The subjects to be covered will include classification, bibliography, special library routine, recording and filing of research material, abstracting, the use of statistics, documentary reproduction, editorial work and the compilation of technical information bulletins. The fee for the whole course (twelve lectures) will be $£ 5$ 5s., but applicants may, if they wish, attend six lectures only at a fee of $£ 215 s$. Lecture programmes and application forms can be obtained from the General Secretary, ASLIB, 52 Bloomsbury Street, W.C.1.

\section{Announcements}

ON the joint recommendation of the presidents of the Royal Society and the Institution of Civil Engineers, the Council of the Institution of Civil Engineers has awarded the James Alfred Ewing Medal for 1945 to Prof. R. V. Southwell, rector of Imperial College of Science and Technology, London, for specially meritorious contributions to the science of engineering in the field of research.

The Rev. D. O'Conneld, S.J., of Riverview College Observatory, New South Wales, states in the course of a letter that Dr. H. P. Berlage, jun., of the Royal Observatory, Batavia, who is well known for his work on the origin of the solar system, is now in Bandoeng after spending three and a half years in a Japanese internment camp in Java.

A symposium arranged by the Road and Building Materials Group of the Society of Chemical Industry will be held on May 8 at the Royal Institution to discuss "Shrinkage and Cracking of Cementive Materials". This symposium has been organised in conjunction with the Ministry of Works so that men of science working on topics connected with urgent problems in the building campaign will have the opportunity of making their contribution. There will be two sessions : 10.30 a.m. to 12.30 p.m. and 2.30 p.m. to 5 p.m.

THe Scientific Film Association (34 Soho Square, London, W.1) has voluntarily undertaken the task of preparing a comprehensive and up-to-date catalogue of the films of scientific interest whioh are available for general distribution in Great Britain. This work is being published by the Association of Special Libraries and Information Bureaux and will be ready this month. It contains details of 600 films, many of which have been appraised and the majority graded. The catalogue is to be sold at five shillings per copy to non-members of the Scientific Film Association. It is proposed to issue supplements from time to time to keep the catalogue up to date. 